\title{
Pengaruh pupuk organik cair limbah ikan nila (Oreochromis niloticus) terhadap pertumbuhan tanaman bayam hijau (Amaranthus viridis L.)
}

\author{
Sultoniyah ${ }^{1 *}$, Ambar Pratiwi ${ }^{2}$ \\ Biologi, Fakultas Sains dan Teknologi Terapan, Universitas Ahmad Dahlan \\ Jl. Jendral Ahmad Yani (Ringroad Selatan) Tamanan, Banguntapan, Bantul \\ Daerah Istimewa Yogyakarta 55191 \\ 1Sultoniyah@yahoo.com*; 2 Ambar@bio.uad.ac.id \\ *korespondensi penulis
}

\begin{abstract}
Abstrak
Limbah ikan merupakan hasil samping dari suatu usaha bisa berupa padatan ataupun cairan yang belum mempunyai nilai ekonomis. Limbah ikan yang tidak dimanfaatkan akan mencemari lingkungan seperti air dan udara, misalnya penyuburan ganggang dan menyebabkan bau tidak sedap. Oleh sebab itu, upaya yang dilakukan untuk meminimalisir limbah ikan agar bermanfaat yaitu mengolah limbah ikan menjadi pupuk organik cair (poc). Tujuan dari penelitian ini menentukan pengaruh poc limbah ikan nila $(O$. niloticus) terhadap pertumbuhan tanaman bayam hijau (A. viridis $\mathrm{L}$.) dan menentukan dosis poc limbah ikan nila yang menghasilkan pertumbuhan bayam hijau paling optimal. Rancangan Acak Lengkap adalah rancangan yang digunakan dalam penelitian ini dengan lima perlakuan dan lima ulangan. Lima perlakuan tersebut yaitu $\mathrm{P} 0=0 \mathrm{~mL} / \mathrm{L} ; \mathrm{P} 1=3 \mathrm{~mL} / \mathrm{L} ; \mathrm{P} 2=8$ $\mathrm{mL} / \mathrm{L} ; \mathrm{P} 3=13 \mathrm{~mL} / \mathrm{L} ; \mathrm{P} 4=18 \mathrm{~mL} / \mathrm{L}$ dan $\mathrm{P} 5=23 \mathrm{~mL} / \mathrm{L}$. Parameter pengamatan yang digunakan meliputi tinggi batang, panjang dan lebar daun, berat basah, berat kering serta kadar klorofil. Hasil pengaruh parameter pertumbuhan diuji dengan Anova menunjukkan tidak terdapat pengaruh yang signifikan terhadap parameter pengamatan. Perlakuan P1 merupakan perlakuan yang paling baik untuk pertumbuhan tanaman bayam hijau terutama mendukung parameter panjang dan lebar daun serta berat kering.

Kata kunci: poc, limbah ikan nila, pertumbuhan, Amaranthus viridis L.
\end{abstract}

\begin{abstract}
Fish waste is a by-product of a business that can be in the form of solids or liquids that do not yet have economic value. Fish waste that is not utilized will pollute the environment such as water and air, for example algae enrichment and cause unpleasant odors. Therefore, efforts are made to minimize fish waste to be useful, namely processing fish waste into liquid organic fertilizer (poc). The purpose of this study is to determine the influence of poc tilapia waste (O. niloticus) on the growth of green spinach plants (A. viridis L.) and determine the poc dose of tilapia waste that produces the most optimal growth of green spinach. A Completely Randomized Design is a design used in this study with five treatments and five replications. The five treatments are $\mathrm{P} 0=0 \mathrm{~mL} / \mathrm{L} ; \mathrm{P} 1=3 \mathrm{~mL} / \mathrm{L} ; \mathrm{P} 2=$ $8 \mathrm{~mL} / \mathrm{L} ; \mathrm{P} 3=13 \mathrm{~mL} / \mathrm{L} ; \mathrm{P} 4=18 \mathrm{~mL} / \mathrm{L}$ and P5 = $23 \mathrm{~mL} / \mathrm{L}$. Observation parameters used included stem height, leaf length and width, wet weight, dry weight and chlorophyll content. The results of the growth parameters tested with Anova showed no significant effect on the observed parameters. P1 treatment is the best treatment for the growth of green spinach plants, especially supporting the length and width of the leaf and dry weight parameters.
\end{abstract}

Keywords: liquid organic fertilizer, tilapia waste, growth, Amaranthus viridis $\mathrm{L}$. 


\section{PENDAHULUAN}

Limbah adalah hasil samping dari kegiatan usaha berupa padat atau cair yang belum mempunyai nilai ekonomis. Kegiatan usaha yang menghasilkan limbah salah satunya adalah pasar. Salah satu contoh dari limbah pasar adalah limbah padat ikan. Limbah padat ikan yang tidak dimanfaatkan akan mencemari lingkungan seperti air dan udara. Misalnya menyebabkan ganggang menjadi subur dan menimbulkan aroma tidak sedap. Menurut Ibrahim (2005), limbah ikan mempunyai nutrien organik tinggi yang dapat menyebabkan eutrofikasi apabila di perairan umum sehingga ganggang akan subur, organisme akan mati dan pendangkalan terjadi. Aroma tidak sedap disebabkan karena limbah ikan merupakan bahan organik yang mudah membusuk. Menurut Harianti (2012), limbah ikan selama ini dimanfaatkan sebagai tepung ikan, silase ikan, kecap ikan dan terasi ikan sehingga menjadi suatu produk yang mempunyai nilai ekonomis. Pengolahan limbah ikan menjadi poc yaitu salah satu cara yang bisa dilakukan untuk meminimalisir pencemaran lingkungan.

Limbah ikan yang dijadikan poc berasal dari limbah ikan nila (Oreochromis niloticus) yaitu jeroan. Menurut Hossain dan Alam (2015), kadar abu yang terdapat dalam jeroan ikan sebesar 4,75\% dan protein sebesar 14,01\%. Menurut Sukrasa dalam Kurniawati (2004), kadar fosfor yang terdapat dalam jeroan ikan sebesar 1\% sampai 1,9\%. Penelitian tentang pengaruh poc terhadap pertumbuhan tanaman telah dilakukan. Hasil penelitian Zahroh dkk. (2018), perbandingan variasi konsentrasi poc limbah ikan menunjukkan pengaruh yang signifikan terhadap jumlah daun dan tinggi batang tanaman cabai merah (Capsicum annum L.). penelitian Abror dan Rakhmad (2018), efektifitas poc limbah ikan dan Trichoderma sp. menunjukkan interaksi variabel pengamatan seperti panjang tanaman, jumlah daun, diameter batang, berat basah dan berat kering tanaman kailan (Brassica oleraceae L.).

Tanaman bayam merupakan tanaman sayuran yang mudah ditemukan di Indonesia. Menurut Direktorat Jenderal Holtikultura (2017), produksi bayam mengalami penurunan dari 1,602,471 kuintal menjadi 1,482,885 kuintal. Pemanfaatan bayam semakin meluas, selain dikonsumsi sebagai sayuran, bayam digunakan sebagai bahan dasar pembuatan mie dan keripik. Usaha untuk meningkatkan prosuksi bayam dapat dilakukan dengan cara pemberian poc. Perbedaan penelitian ini dengan penelitian sebelumnya terletak pada bahan dan komposisi pembuatan poc, tanaman yang digunakan, dan parameter pertumbuhan yang diamati. Oleh karena itu, penelitian mengenai pengaruh poc limbah ikan nila terhadap pertumbuhan tanaman bayam hijau perlu dilakukan. 


\section{METODE}

Persiapan limbah ikan nila

Limbah ikan nila berupa jeroan yang diperoleh dari pasar daerah Kotagede Yogyakarta dikumpulkan, dicuci, dan kemudian dihaluskan.

Pembuatan POC

Jeroan ikan ditimbang sebesar 200 gram. Jeroan tersebut dimasukkan ke dalam fermentor dan diikuti dengan penambahan air gula sebanyak $100 \mathrm{~mL}$ dan air $1 \mathrm{~L}$ dan EM4 $150 \mathrm{~mL}$. Selanjutnya fermentasi dilakukan selama 23 hari. Pengujian sampel poc dilakukan di Laboratorium CV. Chemix Pratama.

Persiapan media tanam

Media tanam yang digunakan pada penelitian ini adalah tanah pekarangan. Tanah dimasukkan ke dalam polybag ukuran $25 \times 25 \mathrm{~cm} 2$ sebanyak $2 \mathrm{~kg}$ per polybag.

Pemilihan benih dan Penyemaian benih

Biji bayam direndam dengan air hangat selama 10 menit. Biji bayam yang tenggelam itulah yang terpilih. Selanjutnya, biji bayam disebarkan ke tanah untuk proses penyemaian selama 14 hari. Bibit siap dipindahkan ke media tanam untuk aklimatisasi selama 4 hari.

Penanaman dan Pemupukan

Bibit bayam yang telah diadaptasikan (dihitung sebagai 0 hari setelah tanam (HST)) siap diberi perlakuan poc. Poc disiramkan sesuai dosis yang diberikan yaitu P0 $=0 \mathrm{~mL} / \mathrm{L} ; \mathrm{P} 1=3$ $\mathrm{mL} / \mathrm{L} ; \mathrm{P} 2=8 \mathrm{~mL} / \mathrm{L} ; \mathrm{P} 3=13 \mathrm{~mL} / \mathrm{L} ; \mathrm{P} 4=18 \mathrm{~mL} / \mathrm{L} ; \mathrm{P} 5=23 \mathrm{~mL} / \mathrm{L}$. Penyiraman dilakukan satu minggu sekali dengan volume penyiraman $200 \mathrm{~mL}$.

Perawatan dan Pengamatan

Perawatan dilakukan dengan penyiangan, memeriksa dan menyingkirkan hama tanaman yang mengganggu tanaman tanpa merusak tanaman. Pengamatan terhadap semua parameter dilakukan pada hari ke-0 HST, 7 HST, 14 HST, 21 HST dan 28 HST kecuali berat basah, berat kering dan kadar klorofil. Penentuan kadar klorofil diukur dengan spektrofotometer (Setiari dan Yulita, 2009) dengan modifikasi yaitu daun ditimbang sebesar 0,5 mg, daun dihaluskan dan ditambah dengan pelarut aseton $10 \mathrm{~mL}$ dengan perbandingan berat sampel dan larutan 1 : 100 dan diukur absorbansinya dengan spektrofotometer UV Vis dengan panjang gelombang $644 \mathrm{~nm}$ dan $663 \mathrm{~nm}$.

Perhitungan kandungan klorofil ditentukan dengan rumus:

Klorofil a = 1,07 (OD 663) - 0,094 (OD 644) 


$$
\begin{aligned}
& \text { Klorofil } b=1,77(\text { OD 644 })-0,28(\text { OD 663) } \\
& \text { Klorofil total = 0,79 (OD 663) + 1,076 (OD 644) }
\end{aligned}
$$

Parameter lingkungan yang diukur yaitu suhu udara dan kelembapan udara. Pengukuran dilakukan pada 0 HST, 7 HST, 14 HST, 21 HST dan 28 HST.

Analisis Data

Analisis data yang digunakan yaitu Anova dengan satu faktorial dan dilanjutkan uji Duncan dengan taraf 5\% apabila terdapat beda nyata.

\section{HASIL DAN PEMBAHASAN}

Menurut Zahroh dkk. (2018), jeroan ikan mempunyai potensi untuk dijadikan bahan dalam pembuatan poc karena mempunyai unsur hara yang terkandung di dalamnya. Hasil analisis unsur hara tersebut tertera pada Tabel I.

Tabel I. Hasil pengamatan dan analisis poc limbah ikan nila

\begin{tabular}{ccccc}
\hline No & Parameter & Satuan & Hasil & Permentan \\
\hline 1. & Suhu & ${ }^{0} \mathrm{C}$ & 27 & \\
2. & pH awal & - & 4,6 & $4-9$ \\
3. & pH akhir & - & 3,4 & \\
4. & Warna & - & $\begin{array}{c}\text { Cokelat gelap } \\
\text { Asam }\end{array}$ & \\
5. & Bau & - & & \\
\multicolumn{7}{c}{ Kadar unsur } & & 5,43 & Min 6 \\
6. & Karbon (C) & $\%$ & 0,16 & $3-6$ \\
7. & Nitrogen (N) & $\%$ & 0,22 & $3-6$ \\
8. & Fosfor (P) & $\%$ & 0,09 & $3-6$ \\
9. & Kalium (K) & $\%$ & & \\
\hline
\end{tabular}

Hasil pengukuran suhu poc limbah ikan nila (O. niloticus) diperoleh $27^{\circ} \mathrm{C}$. Pemanenan poc dilakukan ketika suhu telah turun karena laju fermentasi sudah mulai berkurang. Hal ini dikarenakan mikroorganisme yang terdapat dalam EM4 telah menguraikan bahan organik seperti karbohidrat menjadi senyawa yang sederhana. Pengukuran $\mathrm{pH}$ poc menghasilkan $\mathrm{pH}$ awal dan akhir sebesar 4,6 dan 3,4. Kondisi larutan poc yang dihasilkan asam. Hal ini terjadi karena aktivitas mikroorganisme penghasil asam organik seperti asam laktat. Menurut Fitria dkk. (2008), proses penguraian bahan organik menghasilkan $\mathrm{pH}$ akhir yaitu asam sampai netral. Warna yang dihasilkan dari poc limbah ikan nila (O. niloticus) yaitu cokelat kegelapan. Warna pupuk tersebut disebabkan karena bahan yang digunakan pada poc berwarna cokelat. Menurut Sumarto dan Pareng (2014), limbah ikan nila menghasilkan pupuk berwarna cokelat sampai gelap dan pekat. Bau yang dihasilkan setelah proses pemanenan poc yaitu bau asam. Menurut Lestari (2017), kondisi poc yang asam dikarenakan 
aktivitas mikroorganisme dalam menguraikan bahan organik di dalam pupuk. Selain diuji fisik, poc limbah ikan nila (O. niloticus) juga di uji secara kimia seperti analisis unsur hara yang terkandung di dalam pupuk. Hasil analisis yang diperoleh unsur C sebesar 5,43\%, unsur $\mathrm{N}$ sebesar 0,16\%, unsur $\mathrm{P}$ sebesar 0,22\% dan unsur $\mathrm{K}$ sebesar 0,09\%. Hasil analisis kandungan unsur hara lebih rendah dari Peraturan Pertanian No.70/Permentan/SR.140/10/2011 tentang Persyaratan Teknis Minimal POC.

Pertumbuhan ialah proses pertambahan ukuran maupun volume suatu tanaman yang sifatnya tidak dapat kembali atau irreversible (Salisbury dan Ross, 1995).

Tabel II. Hasil pengukuran parameter tanaman bayam hijau (A. viridis L.) umur 28 HST

\begin{tabular}{cccccc}
\hline \multirow{2}{*}{$\begin{array}{c}\text { Perlakua } \\
\mathbf{n}\end{array}$} & $\begin{array}{c}\text { Tinggi } \\
\text { batang }(\mathbf{c m})\end{array}$ & $\begin{array}{c}\text { Panjang } \\
\text { daun }(\mathbf{c m})\end{array}$ & $\begin{array}{c}\text { Lebar } \\
\text { daun }(\mathbf{c m})\end{array}$ & $\begin{array}{c}\text { Berat } \\
\text { basah } \mathbf{( g )}\end{array}$ & $\begin{array}{c}\text { Berat } \\
\text { kering (g) }\end{array}$ \\
\hline P0 & 46,60 & 3,86 & 2,45 & 28,82 & 2,46 \\
P1 & 47,86 & $\mathbf{4 , 2 5}$ & 3,00 & 34,83 & $\mathbf{3}, 31$ \\
P2 & 48,40 & 3,99 & 2,50 & 29,29 & 2,57 \\
P3 & $\mathbf{5 0 , 1 0}$ & 2,61 & 2,49 & 35,68 & 2,81 \\
P4 & 41,76 & 3,34 & 2,28 & 22,89 & 1,68 \\
P5 & 44,32 & 3,11 & 2,14 & 28,48 & 2,26 \\
\hline
\end{tabular}

Menurut Prasetyo (2014), tinggi batang adalah parameter pertumbuhan tanaman yang digunakan untuk mengetahui perlakuan yang diberikan ke tanaman memiliki pengaruh atau tidak. Parameter tinggi batang dipilih dalam penelitian ini karena unsur hara seperti $\mathrm{N}$ yang ada di pupuk berperan dalam pertumbuhan tinggi batang.

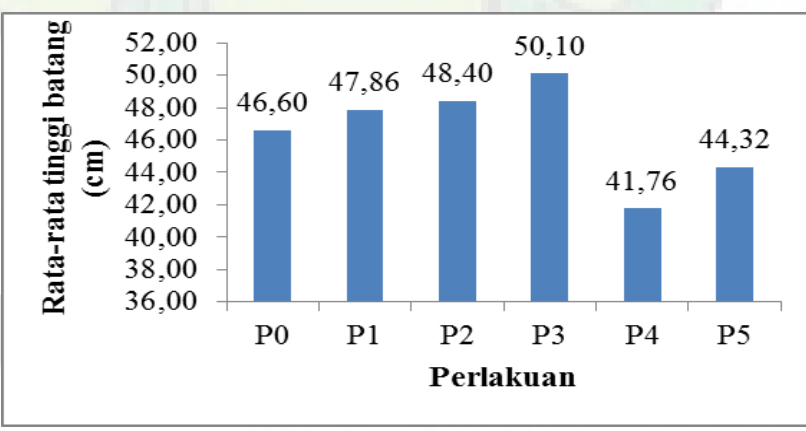

Gambar 1. Diagram rerata tinggi batang bayam hijau

$$
\text { (A. viridis L.) Umur } 28 \mathrm{HST}
$$

Keterangan:

$$
\begin{array}{ll}
\mathrm{P} 0=\text { Dosis POC } 0 \mathrm{~mL} / \mathrm{L} & \mathrm{P} 3=\text { Dosis POC } 13 \mathrm{~mL} / \mathrm{L} \\
\mathrm{P} 1=\text { Dosis POC } 3 \mathrm{~mL} / \mathrm{L} & \mathrm{P} 4=\text { Dosis POC } 18 \mathrm{~mL} / \mathrm{L} \\
\mathrm{P} 2=\text { Dosis POC } 8 \mathrm{~mL} / \mathrm{L} & \mathrm{P} 5=\text { Dosis POC } 23 \mathrm{~mL} / \mathrm{L}
\end{array}
$$

Diagram rerata tinggi batang tanaman bayam hijau (Gambar 1.) menunjukkan rerata tertinggi terdapat di perlakuan P3 yaitu sebesar 50,10 cm. Unsur hara yang berperan dalam 
pertumbuhan tinggi batang adalah N. Unsur ini berperan dalam penyusunan klorofil, hormon auksin dan sitokinin yang dapat merangsang tinggi batang tanaman bayam. Hormon auksin dan sitokinin merupakan faktor yang dapat mempengaruhi tinggi batang. Menurut Wahyudi (2014), hormon auksin berperan untuk menstimulir pembelahan sel sehingga menyebabkan penambahan tinggi tanaman. Menurut Frebort dkk. (2011), hormon sitokinin dihasilkan pada akar dan didistribusikan oleh xylem untuk dibawa ke sel-sel target pada batang sehingga menyebabkan tinggi batang meningkat.

Parameter pertumbuhan yang diukur selain tinggi batang adalah panjang daun dan lebar daun. Menurut Prasetya (2014), pengukuran parameter panjang dan lebar daun adalah parameter morfologi yang sering digunakan untuk mengetahui pengaruh poc. Unsur $\mathrm{N}$ diketahui dapat meningkatkan pertumbuhan tanaman seperti panjang daun dan unsur $\mathrm{N}$ dan $\mathrm{P}$ dapat meningkatkan lebar daun.

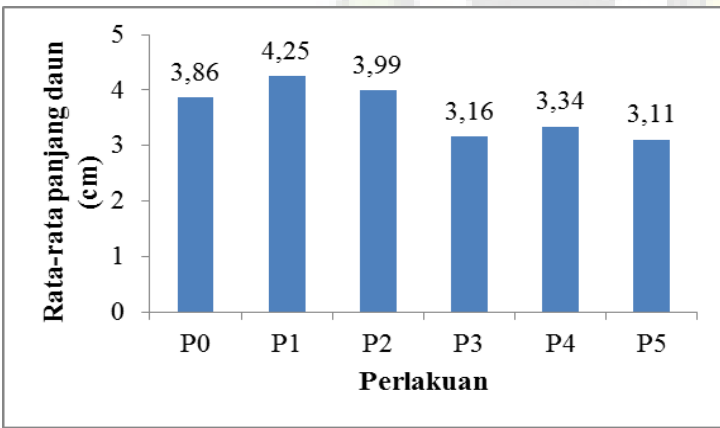

a

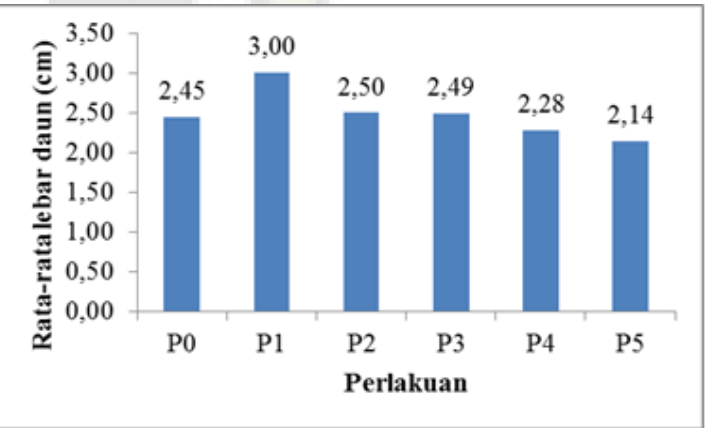

b

Gambar 2. Diagram rerata a) panjang daun, b) lebar daun tanaman bayam hijau (A. viridis L.) umur 28 HST

Keterangan:

$\begin{array}{ll}\mathrm{P} 0=\text { Dosis POC } 0 \mathrm{~mL} / \mathrm{L} & \mathrm{P} 3=\text { Dosis POC } 13 \mathrm{~mL} / \mathrm{L} \\ \mathrm{P} 1=\text { Dosis POC } 3 \mathrm{~mL} / \mathrm{L} & \mathrm{P} 4=\text { Dosis POC } 18 \mathrm{~mL} / \mathrm{L} \\ \mathrm{P} 2=\text { Dosis POC } 8 \mathrm{~mL} / \mathrm{L} & \mathrm{P} 5=\text { Dosis POC } 23 \mathrm{~mL} / \mathrm{L}\end{array}$

Diagram rerata panjang daun (Gambar 2a.) tanaman bayam hijau menunjukkan rerata tertinggi terdapat pada pelakuan P1 sebesar $4,25 \mathrm{~cm}$. Unsur $\mathrm{N}$ pada poc ini dapat meningkatkan pertumbuhan pada tanaman yaitu panjang daun. Unsur $\mathrm{N}$ dapat diserap oleh tumbuhan salah satunya dalam bentuk nitrat. Air dan nitrat dapat diserap oleh rambut-rambut akar. Air dan unsur tersebut akan larut ke sel-sel dan akhirnya akan masuk ke xylem. Xylem mempunyai peran untuk membawa air dan hara ke daun. Air dan unsur tersebut dibutuhkan dalam proses fotosintesis yang terjadi di daun. Fotosintesis menghasilkan glukosa yang digunakan sebagai sumber energi oleh tumbuhan untuk melakukan pertumbuhan panjang daun. 
Rerata tertinggi pertumbuhan lebar daun (Gambar 2b.) tanaman bayam hijau terdapat pada $\mathrm{P} 1$ sebesar 3,00 $\mathrm{cm}$. Unsur $\mathrm{N}$ dapat merangsang pertumbuhan lebar daun karena unsur tersebut merupakan penyusun klorofil yang berperan dalam fotosintesis. Unsur $\mathrm{P}$ dapat terserap oleh tanaman dalam bentuk ion fosfat. Ion ini akan diserap oleh akar melalui bulubulu akar menuju xylem. Xylem akan mengedarkan ion tersebut ke bagian organ tanaman yang membutuhkan dalam hal ini adalah daun. Ion tersebut akan membantu proses fotosintesis yang berperan dalam reaksi gelap. Menurut Liferdi (2010), unsur P berperan menyimpan dan menyalurkan energi dalam bentuk ADP dan ATP.

Berat basah menunjukkan biomassa akibat adanya pembelahan sel dan kandungan air. Pembelahan sel tersebut terjadi pada bagian daun. Parameter ini dipilih karena unsur yang terkandung dalam pupuk diharapkan mampu merangsang berat basah bayam hijau. Rerata tertinggi berat basah terdapat pada perlakuan P3 (Gambar 3a.). Air dan unsur yang tersedia dapat merangsang pertumbuhan tanaman sehingga mempengaruhi berat basah. Unsur yang berperan dalam hal ini adalah K. Kalium dapat terserap oleh akar dalam bentuk ion K+. Air dan ion akan didistribusikan menuju daun. Ion tersebut mempunyai peran untuk membentuk karbohidrat dalam proses fotosintesis yang terjadi di daun. Menurut Taufika dkk. (2011), unsur yang terdapat dalam tanah dan sumbangan dari poc mampu merangsang berat basah tanaman. Unsur P juga berperan dalam pembelahan sel di daun sehingga mengakibatkan daun dalam jumlah yang banyak dan mempengaruhi berat basah. Menurut Polii dalam Sarido dan Junia (2017), berat basah tanaman dapat meningkat karena jumlah daun dan daun berfungsi sebagai sink bagi tanaman. Daun juga mempengaruhi berat basah karena mengandung banyak air.

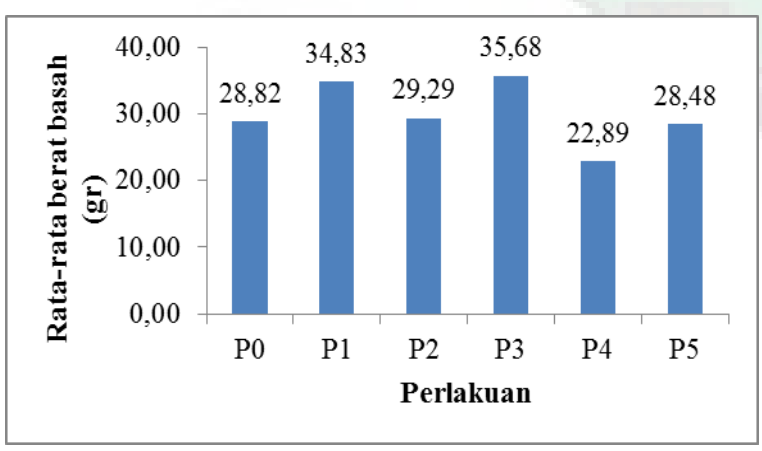

a

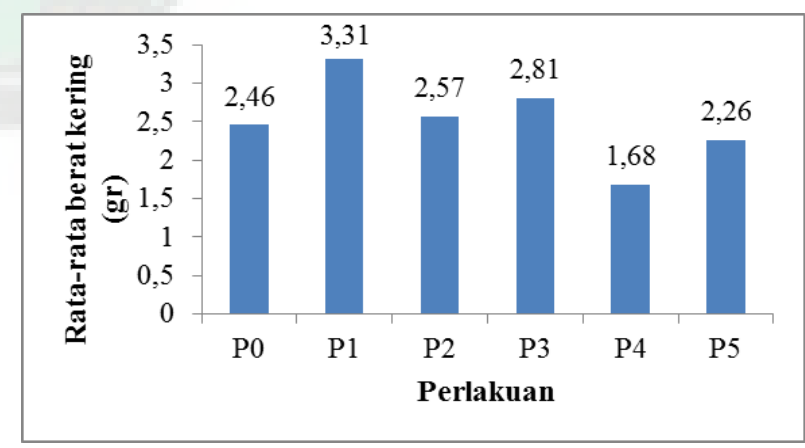

b

Gambar 3. Diagram rerata a) berat basah, b) berat kering tanaman bayam hijau (A.viridis L.) Umur 28 HST

Keterangan:

$\mathrm{P} 0=$ Dosis POC $0 \mathrm{~mL} / \mathrm{L} \quad \mathrm{P} 3=$ Dosis POC $13 \mathrm{~mL} / \mathrm{L}$

$\mathrm{P} 1=$ Dosis POC $3 \mathrm{~mL} / \mathrm{L} \quad \mathrm{P} 4=$ Dosis POC $18 \mathrm{~mL} / \mathrm{L}$

$\mathrm{P} 2=$ Dosis POC $8 \mathrm{~mL} / \mathrm{L} \quad \mathrm{P} 5=$ Dosis POC $23 \mathrm{~mL} / \mathrm{L}$ 
Berat kering merupakan berat tanaman yang mengalami pengeringan melalui oven sampai beratnya mencapai konstan. Berat kering dipilih dalam penelitian ini karena unsur $\mathrm{N}$ dalam poc dapat menyusun klorofil di daun. Tersedianya klorofil dalam jumlah yang cukup menyebabkan fotosintesis dapat bekerja secara optimal. Proses fotosintesis yang bekerja secara optimal otomatis akan menghasilkan fotosintat dalam jumlah yang cukup sehingga hasil berat kering bayam hijau berpengaruh. Hal ini sejalan dengan penelitian Novriani (2014), tersedianya unsur dalam poc apabila tercukupi maka dapat meningkatkan fotosintesis sehingga mempengaruhi hasil fotosintat. Hasil fotosintat yang tinggi dapat mempengaruhi berat kering tanaman. Hal ini dikarenakan berat kering merupakan produk dari proses fotosintesis berupa biomassa yang mencerminkan produktivitas tanaman sebelum dilakukan perlakuan sampai waktu panen. Hasil rerata tertinggi berat kering terdapat pada perlakuan P1 (Gambar 3b.). Hal ini dikarenakan pada dosis tersebut unsur $\mathrm{N}$ dapat diserap dengan maksimal untuk kebutuhan tanaman bayam hijau. Nitrogen berpengaruh terhadap berat kering tanaman. Hal ini disebabkan unsur tersebut merupakan penyusun klorofil. Klorofil terdapat di daun yang mempunyai peran penting di fotosintesis.

Pigmen berwarna hijau pada tanaman hijau adalah klorofil (Gibson dkk, 2017). Parameter kolrofil dipilih karena daun mempunyai klorofil yang berperan dalam proses fotosintesis. Unsur $\mathrm{N}$ yang ada di pupuk mampu merangsang pembentukan klorofil. Unsur tersebut akan terserap dalam bentuk ion nitrat. Ion tersebut akan terserap oleh akar untuk didistribusikan menuju daun. Klorofil akan terbentuk di daun apabila unsur $\mathrm{N}$ terdapat dalam jumlah cukup akan mempercepat pembentukan klorofil di daun. Klorofil apabila tersedia dalam jumlah yang cukup dapat merangsang fotosintesis. Hal ini dikarenakan fotosintesis dapat terjadi karena adanya klorofil dan cahaya matahari. Hal ini sejalan dengan yang dikemukakan oleh Dwidjoseputro (1978), peristiwa fotosintesis akan berlangsung jika terdapat klorofil dan cahaya yang cukup. Menurut Hapsari dan Tjatoer (2013), unsur N diperlukan tanaman untuk pembentukan protein, klorofil serta mempunyai peran dalam proses fotosintesis. Nilai tertinggi klorofil a sebesar $6,43 \times 10-3 \mathrm{mg} / \mathrm{L}$ terdapat pada perlakuan P1. Nilai tersebut menunjukkan perlakuan poc mempunyai kadar klorofil yang tinggi daripada kontrol. Hal tersebut dapat diduga karena kemampuan tanaman yang diberi perlakuan dapat menagkap cahaya lebih efisien sehingga pembentukan klorofil terjadi secara optimal. Menurut Setiari dan Yulita (2009), klorofil a berperan menangkap energi cahaya matahari untuk fotosintesis sedangkan klorofil $b$ berperan sebagai antena fotosintetik dimana cahaya akan dikumpulkan untuk dibawa menuju klorofil a. 


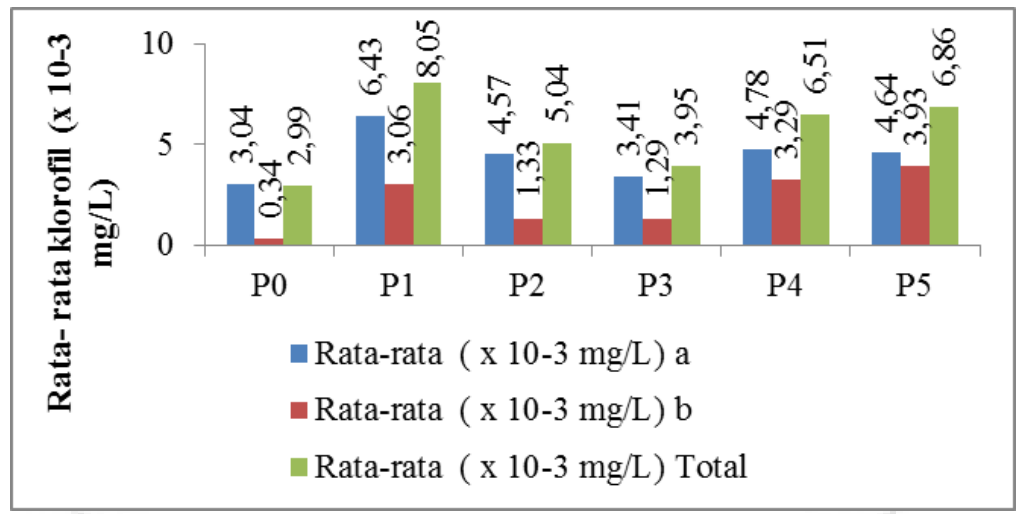

Gambar 4. Diagram kadar klorofil tanaman bayam hijau (A. viridis L.) Umur 28 HST

Keterangan:

$\mathrm{P} 0=$ Dosis POC $0 \mathrm{~mL} / \mathrm{L} \mathrm{P} 3=$ Dosis POC $13 \mathrm{~mL} / \mathrm{L}$

$\mathrm{P} 1=$ Dosis POC $3 \mathrm{~mL} / \mathrm{L} \mathrm{P} 4=$ Dosis POC $18 \mathrm{~mL} / \mathrm{L}$

$\mathrm{P} 2=$ Dosis POC $8 \mathrm{~mL} / \mathrm{L}$ P5 = Dosis POC $23 \mathrm{~mL} / \mathrm{L}$

Pertumbuhan dan perkembangan tanaman dapat dipengaruhi oleh faktor lingkungan. Suhu udara dan kelembapan udara merupakan faktor lingkungan yang diukur dalam penelitian ini. Hasil pengukuran suhu udara dan kelmbapan udara di green house sebesar $34,6^{\circ} \mathrm{C}$ dan $69,9 \%$. Hasil pengukuran tersebut tidak sesuai dengan Saparinto (2013), suhu udara untuk pertumbuhan bayam sebesar $20^{\circ} \mathrm{C}$ sampai $30^{\circ} \mathrm{C}$ sedangkan menurut Merlina (2016), kelembapan udara yang diperlukan bayam untuk dibudidayakan sebesar 20\% sampai $30 \%$. Suhu udara dan kelembapan yang tinggi dapat mempengaruhi penyerapan air dan unsur hara. Penyerapan air dan unsur hara menjadi terhambat dikarenakan stomata dapat membuka. Hal ini dapat menyebabkan air dan unsur hara akan keluar dari sel sehingga tanaman akan kehilangan air dan unsur hara dalam jumlah yang banyak. Selain itu, sel penjaga juga tidak dapat mengakumulasi ion kalium karena keluar dari sel. $\mathrm{pH}$ poc berpengaruh terhadap sifat tanah yang cocok untuk ditumbuhi tanaman bayam. Tanaman bayam cocok untuk dibudidayakan pada pH 6 sampai 7 (Anonim, 2019) sedangkan pupuk organik dalam penelitian ini menghasilkan $\mathrm{pH}$ yang terlalu asam. Kondisi tersebut diduga dapat menyebabkan tanaman tidak merespon pertumbuhan dengan baik sehingga tanaman tidak dapat menyerap unsur dalam poc secara maksimal.

Hasil pengukuran parameter pertumbuhan yang diuji menggunakan Anova menunjukkan tidak ada pengaruh pada semua parameter pertumbuhan. Hal ini dapat dipengaruhi oleh penyiraman air, $\mathrm{pH}$ pada pupuk dan kandungan unsur yang ada di poc. Penyiraman air dilakukan setiap hari pada tanaman kontrol dan tanaman yang diberi poc. Penyiraman yang dilakukan setiap hari akan menyebabkan respon pertumbuhan tanaman hampir seragam pada semua perlakuan karena tanaman hanya seminggu sekali diberikan poc. Poc yang mempunyai 
sifat slow release menyebabkan tanaman menyerap unsur hara sedikit demi sedikit sehingga respon pertumbuhan tanaman tidak begitu nampak. Penentuan dosis terbaik dilakukan dengan cara melihat parameter pertumbuhan yang paling baik diantara masing-masing perlakuan.

\section{SIMPULAN}

Kesimpulan dari penelitian ini adalah poc limbah ikan nila (O. niloticus) terhadap pertumbuhan tanaman bayam hijau (A. viridis L.) tidak menunjukkan adanya pengaruh yang signifikan terhadap parameter pertumbuhan. Dosis pupuk organik limbah ikan nila (O. niloticus) yang menghasilkan pertumbuhan tanaman bayam hijau (A. viridis L.) paling optimal yaitu dosis POC $3 \mathrm{~mL} / \mathrm{L}(\mathrm{P} 1)$.

\section{REFERENSI}

Abror, M. dan Rakhmad, P.H. 2018. Efektivitas Poc dari Limbah Ikan dan Trichoderma sp. Terhadap Pertumbuhan dan Hasil Tanaman Kailan (Brassica oleraceae L.). Jurnal Agrosains dan Teknologi, 3 (1): 1-12.

Direktorat Jenderal Holtikultura. 2017. Produksi Holtikultura. https://holtikultura2.pertanian.go.id/produksi/sayuran.php. Diakses pada tanggal 1 November 2018 pukul 11.17 WIB.

Dwidjoseputro, D. 1978. Pengantar Fisiologi Tumbuhan. Jakarta : PT. Gramedia.

Frebort, Ivo., Marta, K., Tomas, H., Jitka. And Petr, G. 2011. Evolution of Cytokinin Biosyntesis and Degradation. Journal of Experimental, 62 (8): 2431-2452.

Fitria, Y., Bustami, I. dan Desniar. 2008. Pembuatan Poc Limbah Industri Perikanan Menggunakan Asam Asetat dan EM4 (Effective microorganism 4). Jurnal Sumberdaya Perairan, 1 (2): 23-26.

Hapsari, N. Dan Tjatoer, W. 2013. Pemanfaatan Limbah Ikan Menjadi Pupuk Organik. Jurnal Teknik Lingkungan, 2 (1): 1-6.

Harianti. 2012. Pemanfaatan Limbah Padat Hasil Perikanan Menjadi Produk Yang Bernilai Tambah. Jurnal Balik Dewa, 3 (2): 39-46.

Hossain, U. and A. K. M. N., Alam. 2015. Production of Powder Fish Silage From Fish Market Wastes. SAARC J. Agri, 13 (2): 13-25.

Kurniawati, V. 2004. Penggunaan Beberapa Koagulan Untuk Pengolahan Limbah Cair Pabrik Selondok. Skripsi Ilmiah. Semarang: Fakultas Matematika dan Ilmu Pengetahuan Alam Universitas Diponegoro.

Lestari,S., Mukarlina. dan Elvi, R. P. W. 2017. Pertumbuhan Tanaman Bayam Kuning (Amaranthus blitum L.) dengan Pemberian Poc dari Kulit Kecambah kacang Hijau (Vigna radiata L.). Protobiont, 6 (3): 201-206.

Liferdi, L. 2010.Eek Pemberian Fosfor terhadap Pertumbuhan dan Status Hara pada Bibit Manggis. J.Hort, 20 (1): 18-26.

Merlina, A. 2016. Investasi Emas Hijau dari Budidaya Bayam. Jawa Barat : Villam Media. 
Novriani. 2014. Respon Tanaman Selada (Lactuca sativa L.) terhadap Pemberian Poc Asal Sampah Organik Pasar. Klorofil, IX (2): 57-61.

Peraturan Menteri Pertanian No.70/Permentan/SR.140/10/2011 tentang Poc, Pupuk Hayati dan Pembenahan Tanah. Dinas Pertanian.

Prasetyo, J. 2014. Efek Paparan Musik Jazz dan Noise pada Karakteristik Morfologi dan Produktivitas Tanaman Sawi Hijau (Brassica juncea). Jurnal Teknik Pertanian, 2 (1): 17-22.

Salisbury, F. B. dan Ross. 1995. Fisiologi Tumbuhan. Bandung : ITB Press.

Saparinto, C. 2013. Grown Your Own Vegetables-Panduan Praktis Menanam Sayur Konsumsi Populer di Pekarangan. Yogyakarta : Lily Publisher.

Sarido, L. dan Junia. 2017. Uji Pertumbuhan dan Hasil Tanaman Pakcoy (Brassica rapa L.) dengan Pemberian Poc Pada Sistem Hidroponik. Jurnal AGRIFOR, XVI (1): 65-4.

Setiari, N. dan Yulita, N. 2009. Eksplorasi Kandungan Klorofil pada Beberapa Sayuran Hijau Sebagai Alternatif Bahan Dasar Food Supplement. Bioma, 11 (1): 6-10.

Sumarto dan Pareng Rengi. 2014. Uji Penerapan Poc Limbah Ikan Runcah Terhadap Perkembangan Tanaman Sayuran Bayam (Amaranthus sp.) dan Kangkung Darat (Ipomoea reptans). Prosiding Seminar dan Lokakarya Nasional FKPT-TPI. Riau : Fakultas Perikanan Universitas Riau.

Taufik, R., Chaniago, R., Rur, M. dan Ardi. 2011. Pengujian Beberapa Dosis Poc Terhadap Pertumbuhan dan Hasil Tanaman Wortel (Daucus carota L.). Jerami, 4 (3): 175-184.

Wahyudi. 2014. Pertumbuhan Pohon dan Jaringan Pengaman Unsur Hara. Bogor : Isana Press Bogor.

Zahroh, F., dkk. 2018. Perbandingan Variasi Konsentrasi Poc Dari Limbah Ikan Terhadap Pertumbuhan Tanaman Cabai Merah (Capsicum annum L.). Al: Hayat, Journal of Biology and Applied Biology, 1 (1): 50-57. 